\title{
A systematic approach for surface exploration of sites - analysis of international exploration programs
}

\author{
Lisa Richter, Thies Beilecke, Raphael Dlugosch, Tilo Kneuker, Lukas Pollok, \\ Nicole Schubarth-Engelschall, and Ralf Semroch \\ Federal Institute for Geosciences and Natural Resources (BGR), Hannover, 30655, Germany \\ Correspondence: Lisa Richter (lisa.richter@bgr.de)
}

Published: 10 November 2021

\begin{abstract}
The site selection procedure for a high-level radioactive waste repository in Germany is based on the Repository Site Selection Act (StandAG, 2017), which comprises three phases. In phase 2 the Federal Company for Radioactive Waste Disposal (BGE) will conduct surface exploration. Based on the exploratory findings, the further developed preliminary safety analyses, the common requirements and criteria, and potential socioeconomic analyses will be applied feeding into proposed sites for underground exploration.

Commissioned by the BGE, the Federal Institute for Geosciences and Natural Resources (BGR) contributes to this procedure with the projects GeoMePS and ZuBeMErk, which collate and assess geoscientific and geophysical methods and programs for surface exploration. Their common goal is to develop recommendations for surface exploration of siting regions. For this purpose, the BGR has developed a systematic approach that includes (1) deducing exploration targets, (2) compilation of geoscientific and geophysical exploration methods in a database structure, and (3) analysis of case studies of national and international exploration programs for high-level radioactive waste disposal. Exploration targets are based on the common criteria and requirements as defined by the StandAG. The identified exploration targets (Kneuker et al., 2020) together with a large number of geoscientific and geophysical exploration methods were integrated and linked within the BGR database "GeM-DB". All methods were evaluated according to their suitability and applicability for (a) the three defined host rocks (crystalline rock, claystone, rock salt) and (b) the previously defined exploration targets.

In step (3) the BGR reviews national and international waste disposal programs exploring for crystalline rock, claystone, and rock salt. Here, the focus is on nondestructive and minimally invasive surface exploration techniques, such as geophysical airborne and ground-based methods or investigations in drill holes and on drill cores. The aims are to identify gaps in the method catalogue of the GeM-DB and to infer exploration directives for surface exploration during phase 2. An example is the analysis of the Swedish site selection process, especially the site investigation program. There, the site investigations are, e.g. the basis for the discipline-specific site descriptive models, which were applied for design and safety assessments (SKB, 2001). The Swedish site investigation program along with programs of other countries considering crystalline host rocks, such as Finland and Canada, show a common ground, which could be adapted for surface exploration of crystalline host rock regions in Germany. The assessment and evaluation of selected programs exploring for rock salt and claystone is currently in progress.
\end{abstract}

The entire systematic approach of the projects GeoMePS and ZuBeMErk aims to develop recommendations for a nondestructive and minimally invasive surface exploration program of siting regions in Germany, regarding the lithological, structural, mechanical, and hydrogeological characterization of the different host rock formations.

Kurzfassung. Das Standortauswahlverfahren für ein Endlager für hochradioaktive Abfälle in Deutschland ist in 3 Phasen unterteilt und basiert auf dem Standortauswahlgesetz (StandAG, 2017). In Phase 2 wird die Bundesgesellschaft für Endlagerung (BGE) übertágig erkunden. Diese Resultate werden in den weiterentwickelten vorläufigen Sicherheitsanalysen sowie der erneuten Anwendung der bekannten Anforderungen und Kriterien 
berücksichtigt und fließen zusammen mit potenziellen sozioökonomischen Analysen in die Standortvorschläge für die untertägige Erkundung ein.

Im Auftrag der BGE beteiligt sich die Bundesanstalt für Geowissenschaften und Rohstoffe (BGR) am Verfahren mit den Projekten GeoMePS und ZuBeMErk, in denen geowissenschaftliche und geophysikalische Methoden und Programme zur übertägigen Erkundung zusammengestellt und bewertet werden. Das gemeinsame Ziel ist es, Empfehlungen füür die übertägige Erkundung von Standortregionen zu erarbeiten. Hierfür hat die BGR einen systematischen Ansatz entwickelt, der (1) die Ableitung von Erkundungszielen, (2) die Zusammenstellung geowissenschaftlicher und geophysikalischer Explorationsmethoden in einer Datenbankstruktur und (3) die Analyse von Fallbeispielen nationaler und internationaler Erkundungsprogramme für die Endlagerung hochradioaktiver Abfälle umfasst. Die Erkundungsziele wurden aus den Kriterien und Anforderungen des StandAG abgeleitet. Alle identifizierten Erkundungsziele (Kneuker et al., 2020) wurden zusammen mit einer Vielzahl geowissenschaftlicher und geophysikalischer Untersuchungsmethoden in die BGR-Datenbank GeM-DB integriert und innerhalb dieser verlinkt. Alle Methoden wurden hinsichtlich ihrer Eignung und Anwendbarkeit für (a) die 3 definierten Wirtsgesteine (Kristallgestein, Tonstein, Steinsalz) und (b) die zuvor definierten Erkundungsziele bewertet.

Im dritten Schritt analysiert die BGR nationale und internationale Erkundungsprogramme von Kristallin, Tonstein und Steinsalz. Der Fokus liegt dabei auf zerstörungsfreien und minimalinvasiven übertägigen Erkundungsverfahren, wie geophysikalische Verfahren aus der Luft oder am Boden oder Untersuchungen in Bohrlöchern und an Bohrkernen. Ziel ist es, Lücken im Methodenkatalog der GeM-DB zu identifizieren und Konzepte für die übertätige Erkundung in Phase 2 zu erarbeiten. Ein Beispiel ist die Analyse des schwedischen Standortauswahlprozesses, insbesondere das „Site investigation“ Programm. Diese Untersuchungen sind z. B. die Grundlage für die fachspezifischen Standortbeschreibungen, die für Planung und Sicherheitsuntersuchungen herangezogen wurden (SKB, 2001). Das schwedische „Site investigation“ Programm zusammen mit Programmen anderer Länder mit kristallinen Wirtsgesteinen, wie Finnland und Kanada, zeigen Gemeinsamkeiten, die für die übertägige Erkundung von Kristallin in Deutschland adaptiert werden könnten. Weiterhin werden ausgewählte Programme zur Erkundung von Steinsalz und Tonstein analysiert und ausgewertet.

Der gesamte systematische Ansatz der Projekte GeoMePS und ZuBeMErk hat das Ziel, Empfehlungen für ein zerstörungsfreies und minimalinvasives übertägiges Erkundungsprogramm von Standortregionen in Deutschland zu erarbeiten zur lithologischen, strukturellen, mechanischen und hydrogeologischen Charakterisierung der verschiedenen Wirtsgesteinsformationen.

\section{References}

Kneuker, T., Bartels, A., Bebiolka, A., Beilecke, T., Bense, F., Beushausen, M., Frenzel, B., Jähne-Klingberg, F., Lang, J., Lippmann-Pipke, J., May, F., Mertineit, M., Noack, V., Pollok, L., Reinhold, K., Rummel, L., Schubarth-Engelschall, N., Schumacher, S., Stück, H., and Weber, J. R.: Zusammenstellung von Erkundungszielen für die übertägige Erkundung gemäß §16 Stand AG, Zwischenbericht, Geschäftszeichen B3.2/B50161-17/2020-0001/001, 5 BGR - Bundesanstalt für Geowissenschaften und Rohstoffe, Hannover, 2020.
SKB: Site investigations - Investigation methods and general execution programme, Technical Report TR-01-29, SKB - Svensk Kärnbränslehantering AB, Stockholm, Sweden, 2001.

StandAG: Gesetz zur Aufsuchung und Auswahl eines Standortes für ein Endlager für hochradioaktive Abfälle, Standortauswahlgesetz vom 5. Mai 2017 (BGBI. S. 1074), das zuletzt durch Artikel 12 Absatz 16 des Gesetzes vom 20. Juli 2017 (BGBI. S. 2808) geändert worden ist (Standortauswahlgesetz - StandAG), 2017. 